\title{
An Overview of the Current State of Pallas"s Fish Eagle Population
}

\section{ОБЗОР СОВРЕМЕННЫХ ДАННЫХ О СОСТОЯНИИ ПОПУЛЯЦИИ ОРЛАНА-ДОЛГОХВОСТА}

\author{
Andreyenkov O.V., Andreyenkova N.G. (Institute of Molecular and Cellular Biology of the \\ Siberian Branch of the Russian Academy of Sciences, Novosibirsk, Russia) \\ Андреенков О.В., Андреенкова Н.Г. (ФГБУН Институт молекулярной и клеточной \\ биологии СО РАН, Новосибирск, Россия)
}

\section{Контакт \\ Олег Андреенков \\ Натаиья Андреенкова \\ ИМКБ СО РАН \\ 630090, Россия \\ Новосибирск, просп. \\ акац. Ааврентьева, 8/2 \\ тел.: +73833639042 \\ oleg_andreenkov@ \\ mail.ru \\ www.mcb.nsc.ru}

\section{Contact:}

Oleg Andreyenkov Natalya Andreyenkova Institute of Molecular and Cellular Biology SB RAS

Acad. Lavrentiev Ave. 8/2

Novosibirsk,

Russia, 630090

tel.: +73833639042

oleg_andreenkov@ mail.ru

www.mcb.nsc.ru

\section{Резюме}

Орлан-Аолгохвост (Haliaeetus leucoriphus) - малоизученный хишник с необычной биологией, который находится на грани вымирания. Небольшая гнездяшаяся популяция осталась, по-видимому, только на территории северо-востока Индии и в Банглацеш. Орлан-долгохвост Аолгие годы оставался загадочным видом, благодаря редкости, труднодоступности мия орнитологов мест гнездования, а также из-за необычного образа жизни: он размножается в зимние месяцы, а летом мигрирует на север. На сегодняшний момент каждая встреча этого хищника в местах летовок - редкое событие, а в России достоверно известно всего о нескольких зацокументированных встречах за всю историю наблюдений. $А$ ело осложняется тем, что из-за большой редкости вида, любые ошибочные и недостоверные наблюдения могут сильно искажать картину. В этой статье проводится обзор современных митературных данных о состоянии популяции орлана-долгохвоста на гнездовании и на местах летовок, а также приводятся новые Аанные о Аокументированной встрече орлана-долгохвоста на территории Красношёковского района Алтайского края.

Киючевые слова: пернатые хишники, хишные птицы, орлан-Аолгохвост, Haliaeetus leucoriphus.

Поступима в редакцию 15.11.2018 г. Принята к публикации 10.12.2018 г.

\section{Abstract}

The Pallas's Fish Eagle (Haliaeetus leucoriphus) is a little-studied bird of prey with an unusual biology that is on the verge of extinction. A small breeding population apparently remained only in the north-east of India and in Bangladesh. The Pallas's Fish Eagle has remained a mysterious species for many years due to its rarity, inaccessibility of nesting places and also because of its unusual lifestyle: it breeds during the winter months and migrates north in summer. At present, each meeting of this raptor in summering places is a rare event, and only few documented meetings in Russia are known in the recorded history. A complicating factor is that any erroneous and inaccurate observations can greatly distort the picture due to the great rarity of the species. This article provides an overview of current data on the state of the Pallas's Fish Eagle population at nesting and summering places and reports on a new data on the documented meeting of the Pallas's Fish Eagle in the Krasnoshchekovskiy District of the Altai Kray.

Keywords: birds of prey, raptors, Pallas's Fish Eagle, Haliaeetus leucoriphus.

Received: 15/11/2018. Accepted: $10 / 12 / 2018$.

DOI: $10.19074 / 1814-8654-2018-37-54-65$

Орлан-долгохвост (Haliaeetus leucoriphus) - один из четырёх представителей рода Haliaeetus, встречаюшихся на территории России. Согласно данным Красного листа Межлународного Союза Охраны Природы (МСОП), в 1994 г. мяя Аанного вида был ввеАён охранный статус "уязвимый" (VU), а с 2017 г. вих признан вымираюшим (EN) (BirdLife International, 2018). В первой половине XX века вид был широко распространён на огромной территории. В пределах бывшего СССР орлан-долгохвост встречался в Юго-Восточной Европе, включая Украину, в Волго-Уральском регионе, Юго-Восточном Закавказье, на большей части Казахстана и республик Средней Азии, на юге Сибири, вкиючая Алтае-Саянский регион, в Прибайкалье и Забайкаиье вплоть до Амура ( $А$ ементьев, 1951). В тот период имелись публикации о гнездовании вида на территории быв-
The Pallas's Fish Eagle (Haliaeetus leucoriphus) is one of the four representatives of the genus Haliaeetus, found on the territory of Russia. According to the Red List IUCN, the Vulnerable status (VU) was accepted for this species in 1994 , and it has been recognized as Endangered (EN) since 2017 (BirdLife International, 2018). In the first half of the $20^{\text {th }}$ century, the species was widely distributed over a vast territory. Within the former USSR, the Pallas's Fish Eagle was found in Southeastern Europe, including Ukraine, in the Volga-Ural region, Southeast Transcaucasia, in most of Kazakhstan and the republics of Central Asia, in Southern Siberia, including the Altai-Sayan region, in the Baikal region and Transbaikalia up to Amur (Dementiev, 1951). There were publications on the species nesting on the territory of the former USSR, but today these data are ques- 
Взросый орлан-Аолгохвост (Haliaeetus leucoryphus). Амматинская область, Карачингиль, 12.08.2015. Фото О. Белялова.

Adult Pallas's Fish Eagle (Haliaeetus leucoryphus). Almaty region, Karachingil, 12/08/2015. Photo by $O$. Belyalov.

шего СССР, однако сегодня эти данные подвергаются сомнению ввиду отсутствия прямых доказательств (Коваленко, 2009).

Сомнения в достоверности многих ранних данных о встречах орлана-долгохвоста высказывались неоднократно, причём это касается не только данных визуальных наблюдений. Так, например, указывается, что $\Delta в е$ тушки орлана-долгохвоста, со-

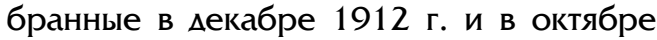
1913 г. в холе Хубсугульской (Косогольской) экспедиции В.С. Елпатьевского в Монголии и храняшиеся в Венском музее естествознания (№№ NMW 42.010 и NMW 42.011), в 2013 г. были переопределены как тушки орлана-белохвоста (Haliaeetus albicilla) (Gilbert et al., 2014). Ставились пол сомнение и переопределялись и мругие, более свежие Аокументированные встречи орлана-долгохвоста. Например, в 2016 г. в Запамно-Казахстанской области (Казахстан) гнездо орла-могильника (Aquila heliaca) было ошибочно определенно, как гнездо орлана-долгохвоста: переопрелеление было выполнено И.В. Феселовым (2016). Не все орнитологи признают встречу орлана-долгохвоста 27 апреля 2011 г. в пойме р. Орель на границе Полтавской и $\Delta$ непропетровской областей Украины (Нахточий, 2012). Это связано с недостаточным качеством единственной имеюшейся фотографии.

Так или иначе, обшепризнанно, что во второй половине $\mathrm{XX}$ века популяция орлана-долгохвоста испытала значительную депрессию численности, приведшую к резкому сокрашению числа встреч. Согласно сегонняшним представлениям, гнездовой ареал вида лежит к югу от Гималаев, главным образом на Индийском субконтиненте на территории Индии, Мьянмы, Пакистана, Банглахеш, Бутана и Китая (BirdLife International, 2018). Причём Аля большинства из этих регионов отсутствуют сколько-нибудь полные современные данные о распределении вила. Так, на территории Пакистана последние исследования датируются серединой 70-х годов XX века, когла численность оценивалась в менее чем 40 гнездящихся пар. Ешё меньше данных сушествует по

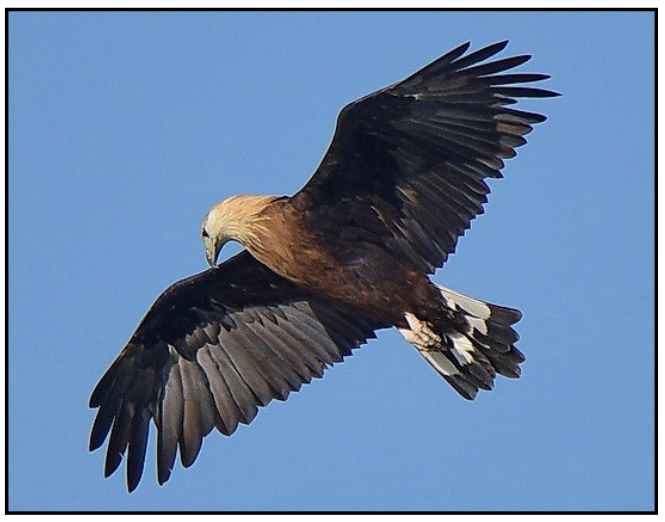

tioned due to a lack of direct evidence (Kovalenko, 2009).

Doubts about the reliability of many earlier data on the Pallas's Fish Eagle meetings have been repeatedly expressed, and this concerns not only visual observations. For example, two individuals of the Pallas's Fish Eagle, collected in December 1912 and in October 1913 during an expedition to Mongolia and stored in the Vienna Museum of Natural History (NMW 42.010 and NMW 42.011), were reidentified in 2013 as White-Tailed Sea Eagles (Haliaeetus albicilla) (Gilbert et al., 2014). Some more recent documented meetings of the Pallas's Fish Eagle were questioned and reidentified as well. For example, in 2016 in the West-Kazakhstan region (Kazakhstan), a nest of Imperial Eagle (Aquila heliaca) was erroneously identified as a nest of the Pallas's Fish Eagle (I.V. Fefelov (2016) redefined it). Not all ornithologists accepted the meeting of the Pallas's Fish Eagle on April 27, 2011 in the Orel' Riverflood plain on the border of Poltava and Dnepropetrovsk Provinces of Ukraine (Nadtochy, 2012). This is due to the insufficient quality of the only available photo.

Anyway, it is generally accepted that population of the Pallas's Fish Eagle experienced a significant number depression in the second half of the 20th century, which led to a sharp reduction in the number of observations. According to current concepts, the breeding range of the species is located southerly of the Himalayas, mainly in the Indian subcontinent: in India, Myanmar, Pakistan, Bangladesh, Bhutan and China (BirdLife International, 2018). Moreover, there is no any complete data on the species distribution for most of these regions. For example, the latest information in Pakistan dated from the mid-70s of the 20th century, when the numbers were estimated at less than 40 breeding pairs. Even less data exists on Myanmar; it was 
Мьянме. Отмечается, что крах численности гнездяшейся популяции орлана-долгохвоста в этой стране произошел очень Аавно - в 30-е годы XX века. После этого в Мьянме регистрироваиись только единичные встречи вида. В Бутане в 2000 г. оставалось единственное жилое гнездо орланаАолгохвоста (Steele, 2017).

На территории Непала гнёзд никогАа не находили, периодически встречали птиц, наиболее вероятно, на миграциях. Интересно отметить, что встречи в XIX и большей части XX века происходили искиючительно в осенние и весенние месяцы, а начиная с 1990-х и, в особенности, в 2000-х годах большая часть встреч стала приходиться на зимние месяцы. Птицы рассматриваются как "зимуюшие" (winter visitor) ^ибо предполагается гнездование. Численность вида на территории страны оценивалась в интервале от 5 Ао 10 особей (Inskipp et al., 2016).

Таким образом, последними странами, гле количество гнездяшихся пар орланаАолгохвоста остаётся хоть сколько-нибудь значительным, являются Индия и Банглацеш. При этом, только мия Банглацеш имеются относительно свежие данные о распространении и численности вида (Sourav et al., 2011). По Аанным авторов этой работы гнездование отмечается по всей территории страны, хотя основные места гнездования сосредоточены в северо-восточных районах. Численность вида на территории страны быстро и постоянно снижается. Авторы основываются на собственных данных, а также на результатах опросов местного населения, которое традиционно считает орлана-долгохвоста свяшенной птицей и ежегодно отмечает reported that the collapse of the nesting Pallas's Fish Eagle population in this country happened a long time ago - in the 1930s. Since then, only single encounters with the species have been reported in Myanmar. The only inhabited nest of the Pallas's Fish Eagle in Bhutan remained in 2000 (Steele, 2017).

Pallas's Fish Eagle nests have never been found on the territory of Nepal, but occasionally birds were seen, most likely migrating ones. It is interesting to note that in the $19^{\text {th }}$ and most of the $20^{\text {th }}$ centuries the eagles were being met exclusively in the autumn and spring months, but since the 1990s, and especially in the 2000s, most of observations happened during the winter months. The birds are considered to be either winter visitors or nesting. The number of the eagles in the country was estimated to range from 5 to 10 individuals (Inskipp et al., 2016).

Thus, the only countries where number of Pallas's Fish Eagle nesting pairs remains signigicant are India and Bangladesh. Relatively recent data on the distribution and abundance of the species is available only for Bangladesh (Sourav et al., 2011). According to this work, Pallas's Fish Eagle breeds throughout the country, although the main nesting sites are concentrated in the northeastern regions. The number of the eagles in Bangladesh is rapidly and constantly decreasing. The authors are based on their own data, as well as on surveys of local people, who traditionally consider the Pallas's Fish Eagle as a sacred bird and annually celebrate returning of the eagles to their nesting sites. The eagles were reported to be present in their nest-
Рис. 1. Распределение занятых гнёзд орланаАолгохвоста (Haliaeetus leucoriphus) в Банглацеш. Карта подготовлена по данным из Sourav et al., 2011.

Fig. 1. Distribution of occupied nests of the Pallas's Fish Eagle (Haliaeetus leucoryphus) in Bangladesh. Map based on data from Sourav et al., 2011.

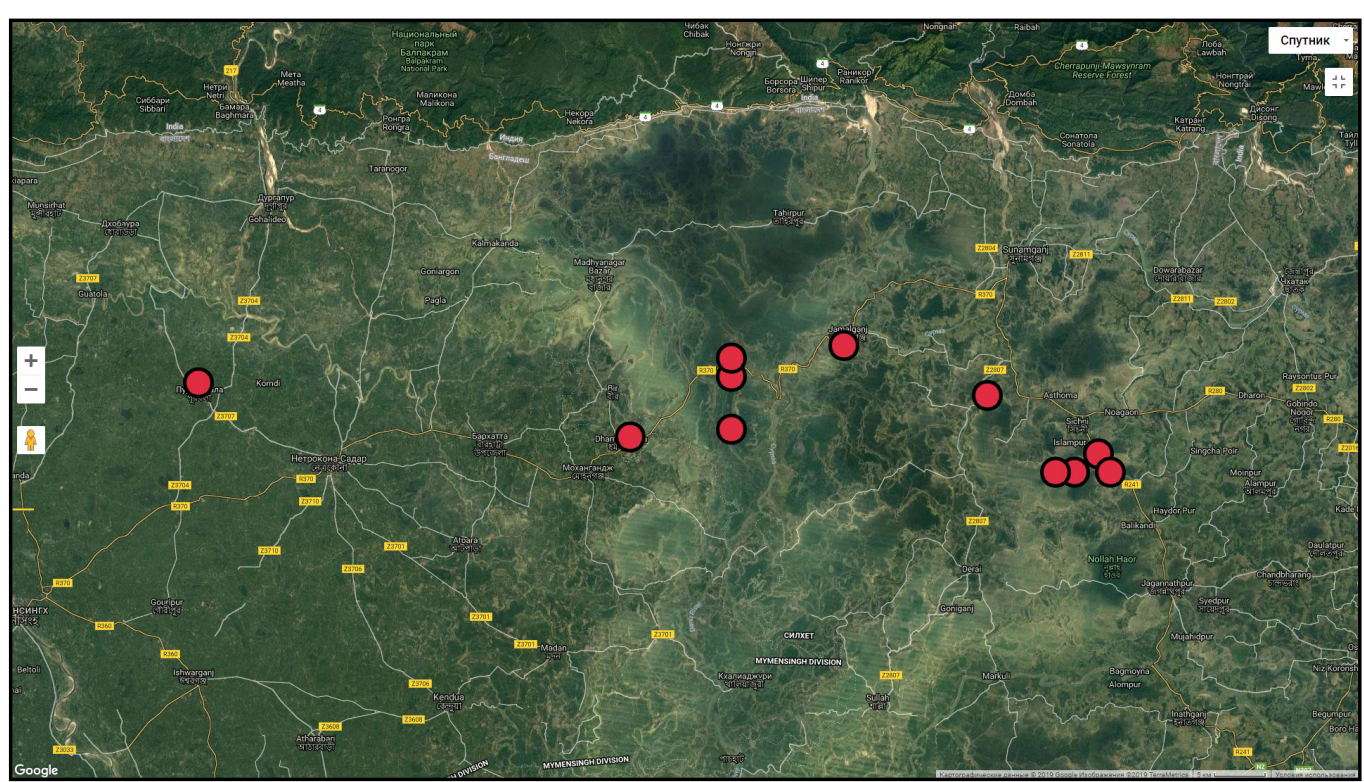


Молодой орлан-долгохвост. Ацматинская область, Сорбулак, 29.06.2014. Фото А. Коваиенко.

Subadult Pallas's Fish Eagle. Almaty region, Sorbulak, 29/06/2014. Photo by A. Kovalenko.

фестивалем дату его возврашения на места гнездования. Указывается, что орланы присутствуют в районах своего гнездования только в период с ноября по апрель. В 80-х годах вокруг 61 деревни находилось как минимум по одному гнезду орлана. К 1999 г. число гнёзд уменьшилось $А$ 22, в 2001-2002 гг. было обнаружено 15 гнёзА, а в 2009 г. авторы нашли только 11 занятых гнёзА (рис. 1).

В Индии орланы на сегодняшний день встречаются только на территории трёх или четырёх штатов, хотя ранее встречамись на территории тринаццати штатов (Steele, 2017). Некоторую нацежду дает лишь тот фракт, что оставшиеся гнездовые участки в этой стране сосредоточены на особо охраняемых природных территориях, преимушественно в Казиранге, Манасе и Намери в штате Ассам.

Необходимо учитывать, что гнездовой период орлана-долгохвоста приходится на зимние месяцы (Sourav et al., 2011; Steele, 2017). Таким образом, все географрические области, лежашие к северу от Гималаев, гАе были засиксированы или фриксируются встречи орланов-Аолгохвостов относятся к территориям летовок. Это подтверждается, во-первых, датами появления птиц на гнездовых участках на территории стран, лежаших к югу от Гималаев, во-вторых, датами встреч орлана-долгохвоста за пределами гнездового ареала и, в-третьих, результатами работы по мечению GPS-рациотрансмиттерами трёх особей орлана-долгохвоста, которые обеспечили единственные имеюшиеся на сегодняшний $е$ ень треки миграций птиц (Steele, 2017). Согласно Аанным GPSтелеметрии, старт весенней миграции птиц на летовку приходится на период с 24 марта по 13 мая, а продолжительность миграции занимает от $21 \Delta 037$ мней. Осенняя миграция стартоваяа в сроки от 23 сентября Ао 10 октября и занимана от 26 Ао 40 нней. Нужно отметить, что все $\triangle$ анные по GPS-рахиомечению были получены от неполовозрелых особей, причём Аве из трёх птиц (сибсы) метились на территории восточной Индии (Национаиьный парк Казиранга, штат Ассам) на одном и том же гнезде, а третья птица была помечена в центрамьной Монголии на зимовке.

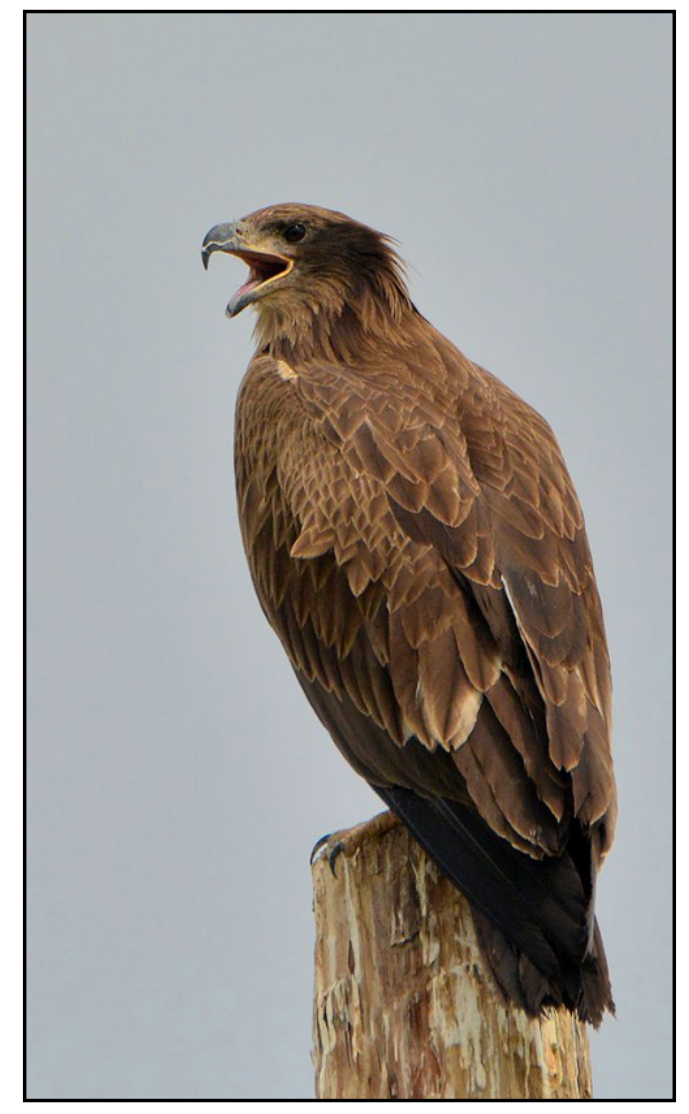

ing areas only from November to April. In the 1980s, there were at least one eagle nest around each of 61 villages. By 1999 the number of nests had been decreased to 22,15 nests were found in 2001-2002, and the authors found only 11 occupied nests in 2009 (fig. 1).

In India, the eagles are found today only in three or four states, although they have been seen in thirteen states before (Steele, 2017). Some hope is given only by the fact that the remaining breeding areas in this country are concentrated in specially protected natural areas, mainly in Kaziranga, Manas and Nameri in the state of Assam.

It should be taken into account that the Pallas's Fish Eagle nesting period falls on the winter months (Sourav et al., 2011; Steele, 2017). Thus, all geographic areas lying to the north of the Himalayas, where Pallas's Fish Eagles have been seen, belong to the summering areas. This conclusion is supported, firstly, by the dates of the birds returning to nesting places, secondly, by the dates of encounters of the Pallas's Fish Eagles outside the nesting range and, thirdly, by GPS tracking of three individuals, providing the only migration tracks currently available for this species (Steele, 2017). According to GPS telemetry, the eagles' spring migration 
Трек осенней миграции последней птицы обрывался по неизвестным причинам при пересечении Гималаев и не был прослежен на всем протяжении. По оценкам автора исследования, эта птица в момент мечения была, по меньшей мере, второго года жизни. Аистанция осенних и весенних миграций во всех случаях превышаяа 4500 км и доходила до 8000 км (рис. 2). Полные треки осенних миграций удалось получИть только ААя ОАНОЙ Из птИЦ, которая родилась в Восточной Индии и на следуюшие Ава сезона возврашалась на территорию соседней страны - Мьянмы. Киючевыми территориями, на которых птицы зацерживались в метние месяцы, оказамись центральная Монголия и $\Delta$ ау-

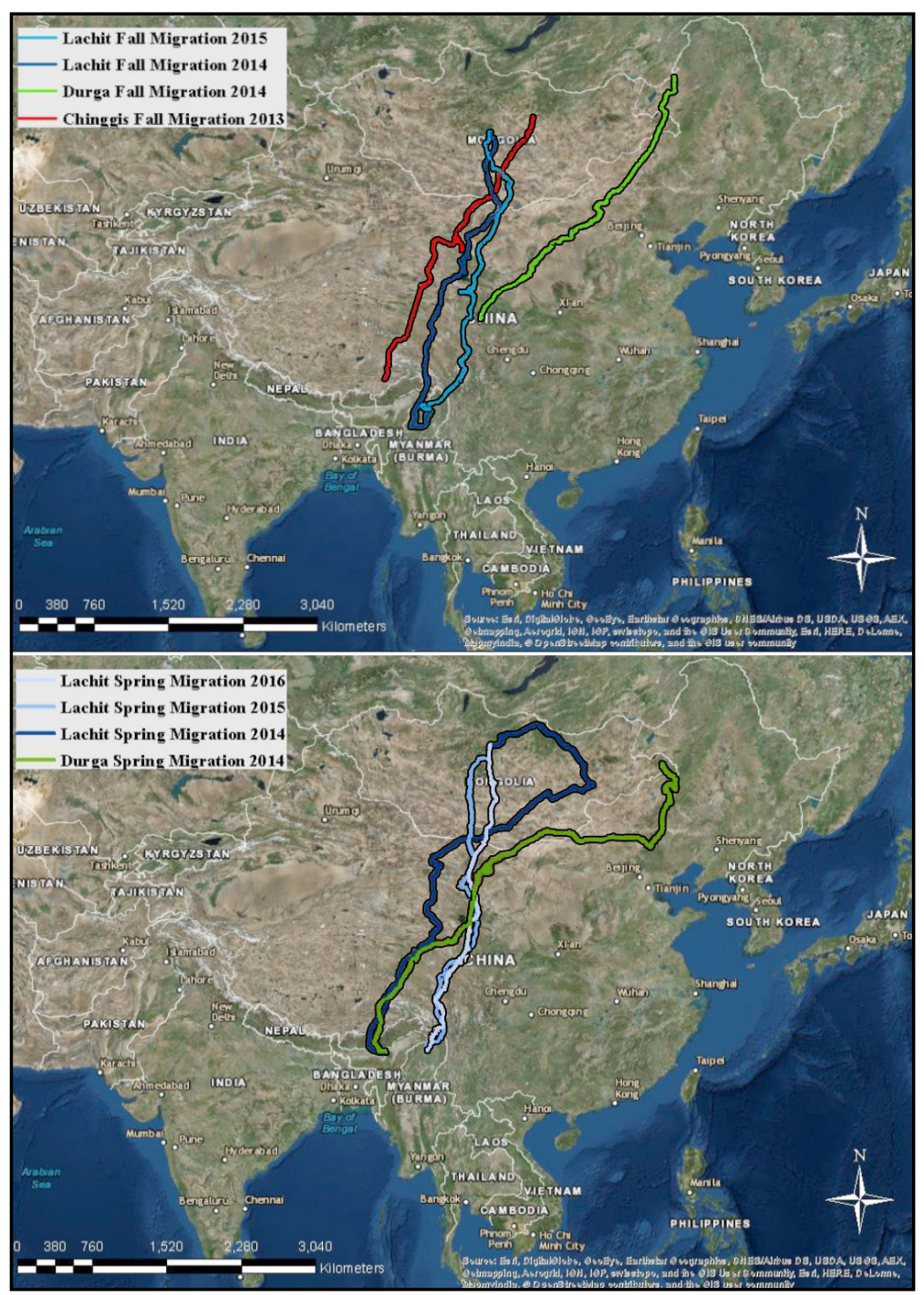

Pис. 2. Маршруты миграции орланов-долгохвостов, помеченных GPSпередатчиками: осенняя миграция Чингиза (красный), Аурги (зеленый) и Аачит (синий) в 2013-2016 гг. - вверху, и весенняя миграция Аурги (зеленый) и Аачит (синий) в 2014-2016 гг. - внизу, из: Steele, 2017.

Fig. 2. Migration routes of the Pallas's Fish Eagles tagged with GPS transmitters: fall migration routes of Chinggis (red), Durga (green), and Lachit (blue) from 20132016 - upper, and spring migration routes of Durga (green) and Lachit (blue) from 2014-2016 - bottom, from Steele, 2017. for summering srarted in the period from March 24 to May 13 , and the migration took from 21 to 37 days. The autumn migration started in the period from September 23 to October 10 and took from 26 to 40 days. It should be noted that all GPS telemetry data was obtained for immature individuals. The distance of the autumn and spring migrations exceeded $4500 \mathrm{~km}$ in all cases and reached 8000 km (fig. 2). Complete tracks of autumn migrations were obtained only for one of the birds, which was born in East India and returned to the territory of the neighboring country Myanmar for the next two winters. The main territories of the birds staying during the summer months were central Mongolia and Dauria at the border between China and Russia (Steele, 2017).

Thus, the first tracking of the Pallas's Fish Eagle migrations confirmed the idea of migration periods and directions. The greatest number of bird encounters during summering period is known to be related to Mongolia (eBird, 2018). Two of the three tracked birds spent the period from May to September there (Steele, 2017). The most detailed work, that attempted to collect all historical observations of the Pallas's Fish Eagle in Mongolia and also provided new data, was published in 2014 (Gilbert et al., 2014). The authors were looking for Pallas's Fish Eagle at 77 different points in Mongolia for six years from 2005 to 2011 from April to October. Thirty publications were used in the Russian, English, German and Mongolian languages for the period from 1901 to 2009 to obtain information on observation of the Pallas's Fish Eagle in Mongolia. During the work, the eagles were seen only at eight points, for each of which the species had been already met before (fig. 4). The main conclusion of the work is that the Pallas's Fish Eagle does not nest in Mongolia and, apparently, has never been nesting. All the eagle observations published occurred from April to September.

There are a few documented observations of the Pallas's Fish Eagle in Mongolia in Russian sources in the 2000 s. These include an observation of a single young bird in the valley of the Tana-Gol River on the northeast coast of Lake Hovsgol on July 1, 2008 (Popov, Tupitsyn, 2008). An adult bird was met in the north-west of Mongolia at Lake Tolbo-Nur on August 25, 2010 (Vazhov, Bakhtin, 2010). Another adult bird was photographed on the southern shore of Lake 
Рис. 3. Регистрации орланов-Аолгохвостов за период с 2010 по 2018 гг. в евird (2018).

Fig. 3. Records of the Pallas's Fish Eagle between 2005 and 2018 in eBird (2018).

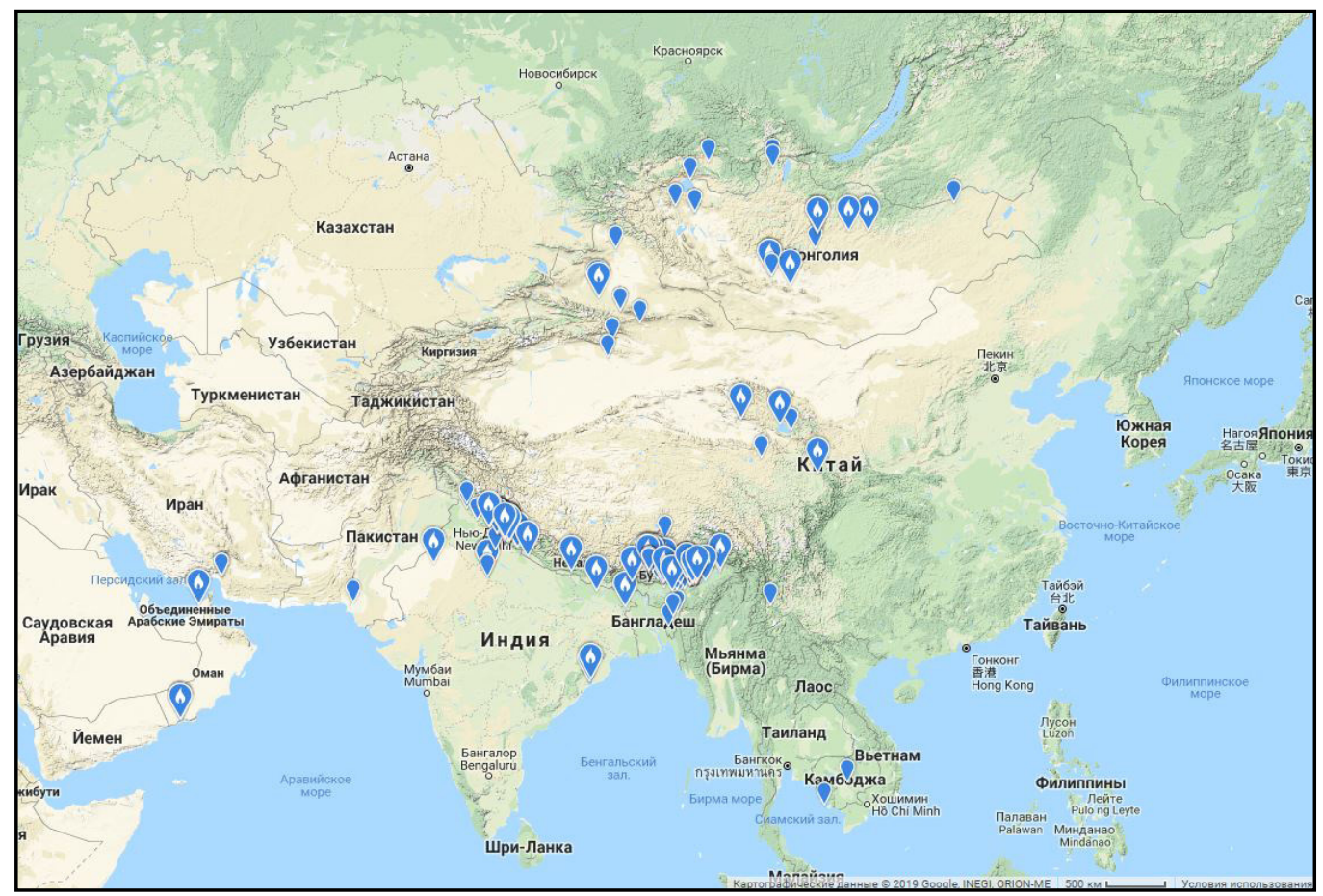

рия на границе межлу Китаем и Россией (Steele, 2017).

Таким образом, первые опыты по отслеживанию миграций орланов-Аолгохвостов подтвердили представление о сезонности и направлении миграций птиц в негнезАовой период. Известно, что наибольшее количество встреч птиц в этот период прихоАится на Монголию (eBird, 2018) (рис. 3). $\Delta$ ве из трёх отслеженных птиц с передатчиками именно здесь проводили период с мая по сентябрь (Steele, 2017). Наиболее помробная работа, гле авторы постарались собрать все исторические наблюдения Аолгохвостов на территории Монголии и объединили их с собственными современными Аанными, вышла в 2014 г. (Gilbert et al., 2014). В течение шести лет с 2005 по 2011 гг. с апреля по октябрь авторы занимаяись поиском орланов-Аолгохвостов в 77 различных точках на территории Монголии. Аия 21 точки из посешенных сушествоваии исторические литературные свидетельства встреч орлана-долгохвоста. Было использовано 30 митературных источников на русском, английском, немецком и монгольском языках за период с 1901 по 2009 гг., в которых упоминамось о встречах вида на территории Монголии. В ходе работ орлан-долгохвост был встречен только в восьми точках, мия кажАой из которых в прошлом уже были известны встречи вида (рис. 4). Основной вывод авторов из проделанной работы закиючается в том, что в Монголии нет и, повидимому, никогАа не было гнездования
Achit-Nuur north of Khovd city on June 25, 2016 (Schneider, 2016). Regular records of the species during the summer period are known for Kazakhstan as well. There are numerous, confirmed by photographs, observations of young and adult Pallas's Fish Eagles in the south-east of Kazakhstan on the Sorbulak Lakes, in Karachingil and at Lake Zaisan from 2007 to 2015 (Knappen-von den Driesch, 2008; Karpov, Belyalov, 2009; Kovalenko, 2009; Belyalov et al., 2018; RRRCN, 2018). The recent observations of the Pallas's Fish Eagles in Altai, Kazakhstan and Mongolia is shown in fig. 5 .

The first documented observation of the Pallas's Fish Eagle since the mid- $20^{\text {th }}$ century in the Russian territory took place on May 26, 2010 in Nukut District of Irkutsk Province, $1 \mathrm{~km}$ from the Bratsk Reservoir bank. A young bird was photographed (Popov, 2018). The second documented observation in the current century should be that of a bird named Durga, which was tracked by M. Steel (2017), located in Daurian steppe and visited Russian territory during the period from August 8 to September 23, 2014.

The third and the most recent documented observation of the Pallas's Fish Eagle in Russia took place on June 23, 2018 in Altai Kray (fig. 5: 4). A one-year-old bird were flying at about 30-40 meters above the Charysh River to the north-west, at coordinates $51.44866^{\circ} \mathrm{N}, 83.050595^{\circ} \mathrm{E}$. We were watching it, when a Hooded Crow (Corvus cornix) and a Black Kite (Milvus migrans) 


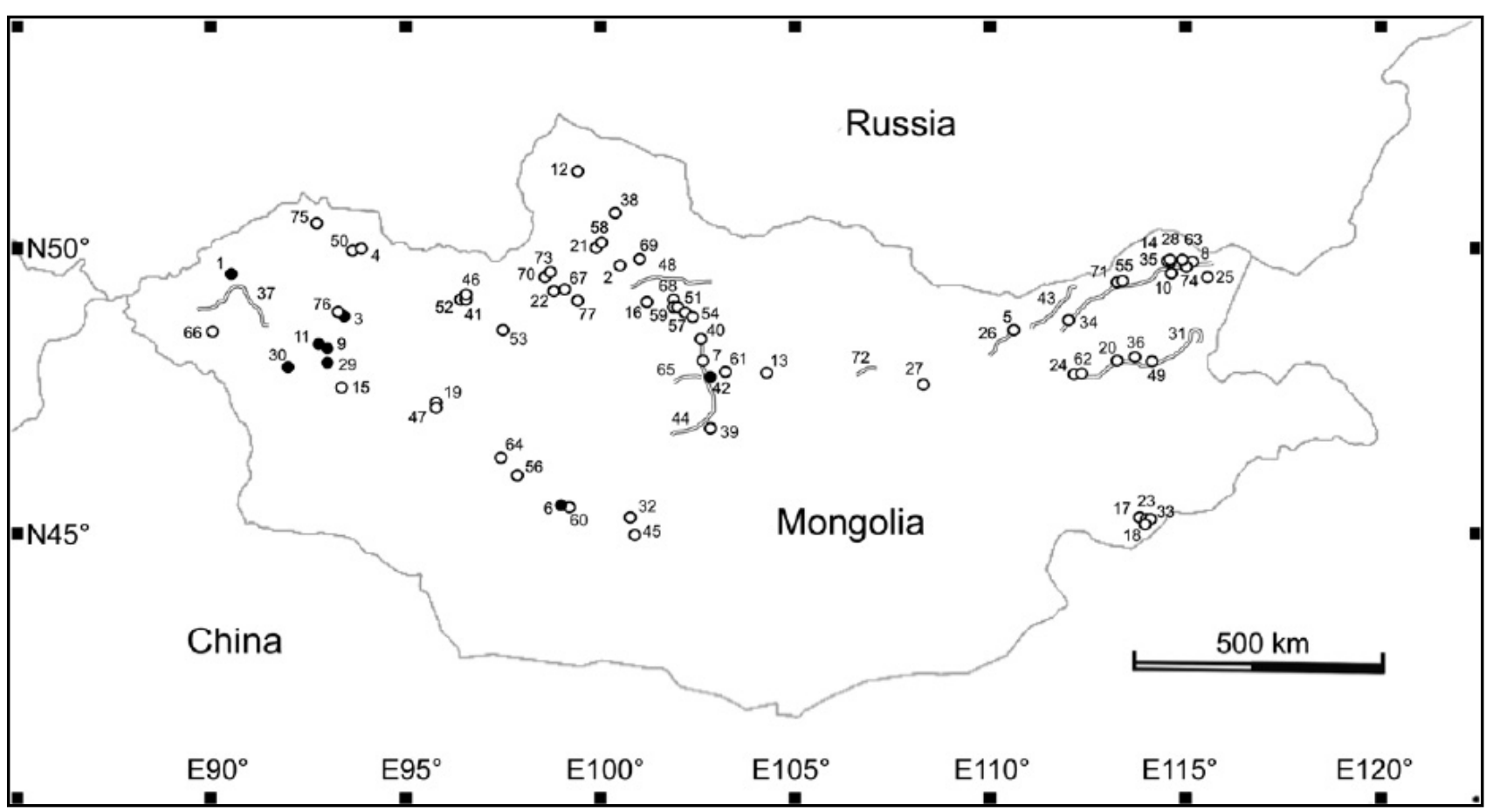

Рис. 4. Карта мест изучения и точек встреч орлана-долгохвоста в Монголии в 2005-2011 гг. Точки исследований на реках и озёрах: белый круг - нет наблюдений орланов, чёрный круг - есть наблюдения орланов. Обследованные участки рек большой протяжённости: белые минии - нет наблюдений орланов. По: Gilbert et al., 2014.

Fig. 4. A map illustrating locations in Mongolia where surveys took place for Pallas's Fish Eagle between 2005 and 2011 . Survey sites include lakes or rivers of limited length (white circle - no eagles observed, black circle - eagles observed), and longer rivers (white lines - no eagles observed) (Gilbert et al., 2014).

Рис. 5. Современные встречи орланов-долгохвостов на Аитае: 1 -05.08.2008,

Ульрике Кнаппен-сон цен $\triangle$ риш;

2 - 25.08.2010,

С.В. Важов;

3 - 25.06.2016,

Е.П. Шнайдер;

4 - 23.06.2018,

А. и Н. Анареенковы.

Fig. 5. Modern records of the Pallas's Fish Eagle in Altai:

1 -05/08/2008

Ulrike Knappen-von

den Driesch;

2 - 25/08/2010,

S.V. Vazhov

3-06/25/2016,

E.P. Schnayder;

4 - 23/06/2018,

$O$. Andreenkov and

N. Andreenkova. орлана-долгохвоста. Все описанные ранее в литературе встречи произошли в период с апреля по сентябрь.

В российских источниках в 2000-х гг. сушествует немного Аокументально полтвержлённых встреч орлана-долгохвоста на территории Монголии. К ним относятся встреча 1 июля 2008 г. оАиночной молоАой птицы в Аолине реки Тана-Гол на севе- started to chase it (fig. 6). The eagle flew up in a spiral trajectory to an approximately 100-150 meters, outran the pursuers and continued flying along the river to the north-west. We managed to take a series of pictures, which was used then to identify the species (Andreyenkov, Andreyenkov, 2018) by I. Karyakin. The eagle was met on the northern edge of the Altai mountains.

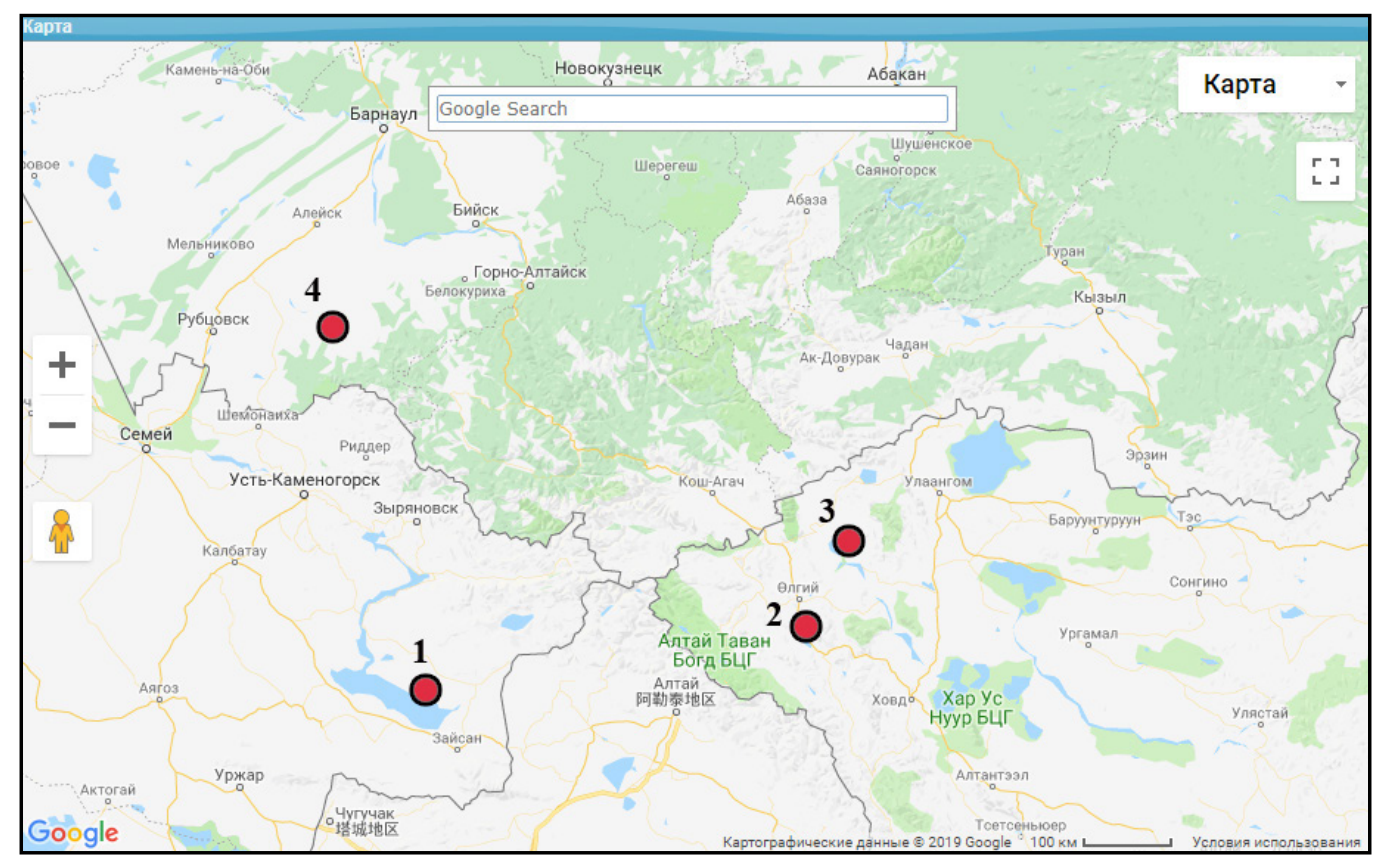


ро-восточном побережье озера Хубсугул (Попов, Тупицын, 2008). Взрослая птица была встречена 25 августа 2010 г. на северо-запаце Монголии на озере Толбо-Нур (Важов, Бахтин, 2010). Аругая взрослая птица была сротограсирована на южном берегу озера Ачит-Нуур севернее г. ХовА 25 июня 2016 г. (Шнайлер, 2016).

Помимо Монголии, регулярные встречи вила в летний период известны на территории Казахстана. Имеются многочисленные, подтверждённые фотограсриями, свидетельства появления молодых и взрослых орланов-долгохвостов на юго-востоке Казахстана на озёрах Сорбулак, в урочише Карачингиль и на оз. Зайсан в период с 2007 по 2015 год (Knappen-von den Driesch, 2008; Карпов, Белялов, 2009; Коваленко, 2009; Белялов и Ар., 2018; RRRCN, 2018).

Современные встречи орланов-Аолгохвостов на Алтае, в Казахстане и в Монгомии отражены на рис. 5.

На территории Российской Федерации первая с середины XX века документально подтверждённая встреча орлана-долгохвоста произошла 26 мая 2010 г. в Нукутском районе Иркутской области в 1 км от берега Братского водохранилиша. Была встречена и сфотограсирована молодая птица (Попов, 2018). Второй Аокументированной встречей в текушем веке следует считать заиёты на территорию страны в течение летнего сезона 2014 г. помеченной GPS-трансмиттером птицы по имени Аурга (Durga) в ходе исследования Марлы Стииль (Steele, 2017). С 16 июня по 23 сентября 2014 г. птица находияась на территории Ааурской степи с периодическими пересечениями Российско-Китайской границы в период с 8 августа по 23 сентября.

Третья и последняя на сегодняшний Аень Аокументированная встреча орлана-долгохвоста на территории России произошиа 23 июня 2018 г. на территории Красношёковского района Аитайского края (рис. 5: 4). В середине Аня годоваиая птица на высоте около 30-40 метров летела нах р. Чарыш вдоль её течения в северо-западном направлении. Мы обнаружики её в точке с координатами 51.4487 ${ }^{\circ}$ с.ш., 83.0506 в.А., когАа она помлетала к автомобильному мосту через р. Чарыш. Вскоре орлана начаяи совместно преследовать серая ворона (Corvus cornix) и чёрный коршун (Milvus migrans) (рис. 6). Орлан по спираяи поднялся на высоту ориентировочно 100-150 метров, оторваися от преследователей и продолжил полёт вАоль течения реки в северо-запацном направлении. УАалось слелать серию фотографий,

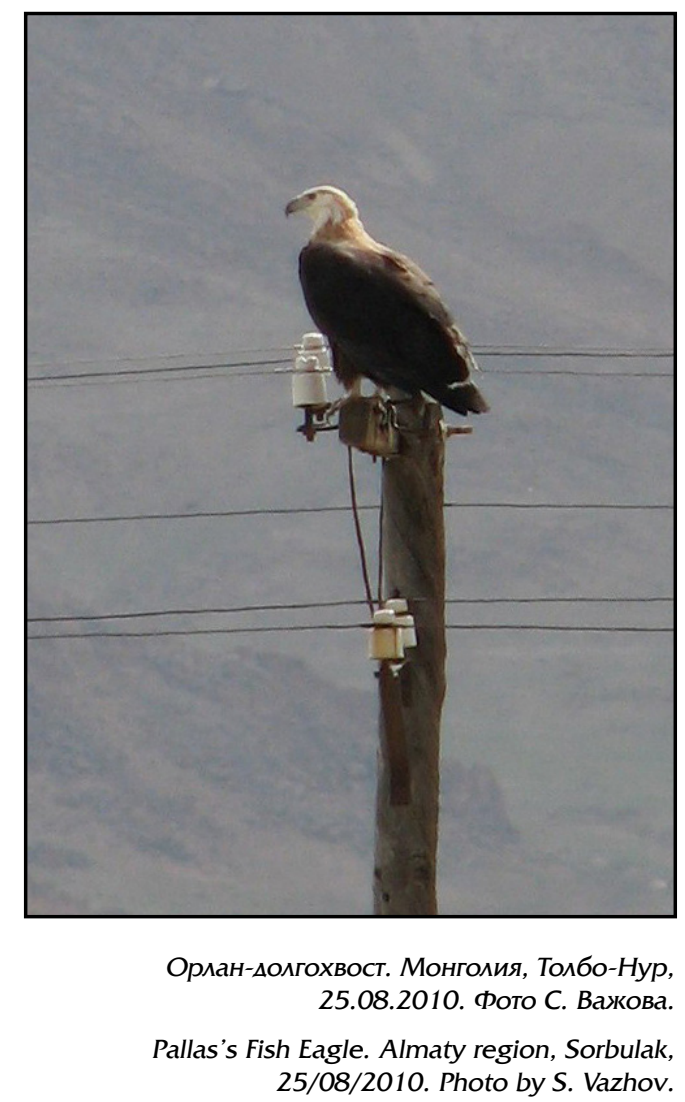

After about $10 \mathrm{~km}$ Charysh valley begins to expand, and after another $10 \mathrm{~km}$ enters the open area of the Pre-Altaian Plain. In this area there are a lot of lakes inside pine forests and the extensive Ob' river floodplain, that could provide a rich hunting resource for Pallas's Fish Eagles.

There is information on observation of the Pallas's Fish Eagle in Altai Kray, not confirmed by photographs: the eagles were seen in the middle part of the Cherginsky Ridge in 1979-1983. (Tsybulin, 1999; Popov, 2002). However, reliability of the species definition is questionable.

Our analysis of the distribution of Pallas's Fish Eagle observations shows that these birds prefer staying near large water bodies, as well as slow rivers with wide floodplains with a lot of oxbows and lakes. A few available data on GPS telemetry confirm this. According to these data, the Pallas's Fish Eagle avoids long movements in the period between migrations and the average area occupied by a non-breeding bird during this period was only about 40-50 $\mathrm{km}^{2}$ (Steele, 2017). Migration dates fall in the spring and autumn months. However, the place where the eagle was met at the Charysh River on June 23, 2018 is different from another places where the eagles 
Рис. 6. Орлан-долгохвост, встреченный 23 июня 2018 г. на территории Красношёковского района А^тайского края (Россия). Фото О. Анареенкова и Н. Андреенковой.

Fig. 6. Pallas's Fish Eag le. Krasnoshchekovsky district of the Altai Kray (Russia), 23/06/2018. Photos by $O$. Andreenkov and N. Andreenkova.

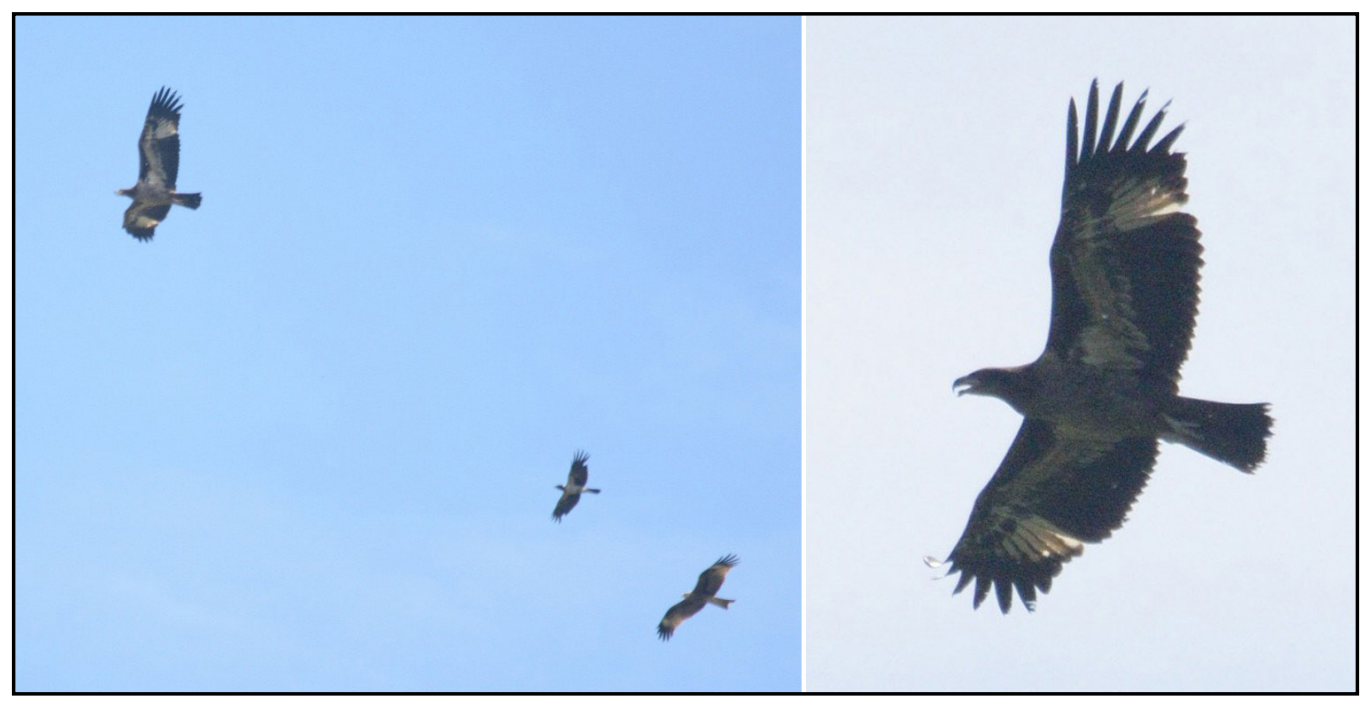

которая впоследствии была использована мля определения виновой принамежности птицы (Андреенков, Андреенкова, 2018). Определил птицу, как молодого орланадолгохвоста И.В. Карякин. Точка встречи орлана находится на северной окраине Аитайской горной системы. Приблизительно через 10 км долина р. Чарыш начинает расширяться, и ешё через 10 км река попаАает на просторы Предалтайской равнины. На этой территории расположено большое количество озёр в ленточных борах и обширная пойма р. Обь и её многочисленных притоков, что обеспечивает богатые охотничьи угодья Аия таких крупных околоводных хищных птиц, как орланы.

Существуют более ранние данные о встречах орлана-долгохвоста на этой территории, не подтвержлённые фотографиями: в периол 1979-1983 гг. орланы встречаиись в среднегорной части Чергинского хребта (Цыбулин, 1999; Попов, 2002). С.М. Цыбулин (1999) связывает появление в этих местах орланов-долгохвостов С возможным сушествованием жилого гнезда в районе ныне не сушествуюшего с. Казанда, находившегося в месте впаления р. Казанда в р. Песчаная. Вывод о возможности гнездования делается на основании летних встреч молодых птиц и одной зимней встречи пары, предположительно взрослых птиц, 23 февраля 1983 г. Возраст птиц в книге не приводится, и собственно остаётся неясность и в правильной идентисрикации вида. Расстояние от устья р. Казанда $\Delta о$ точки встречи орлана-долгохвоста в 2018 г. составляет 138 километров.

Анализ распределения встреч орлановАолгохвостов показывает, что птицы преАпочитают держаться у крупных стоячих were seen in summer, and the date of this observation does not fit the typical periods of migration. It was to be hoped that additional GPS tracking and new observations of the species in Altai will help to understand where the young Pallas's Fish Eagles spend the summer months.

The Pallas's Fish Eagle gives an amazing example of it took more than a century of observations and research to reject the commonplace ideas and understand the biology of a species only in general terms, to sort out the nesting range and migration timing and directions, which are inverted relative to all other migratory birds of the northern hemisphere. This required modern methods, including satellite tracking and various databases, which allow to use information obtained by professional ornithologists and by amateurs as well. Digital photography has become very common and facilitates a confirmation of observations. This is especially important for such a rare species as the Pallas's Fish Eagle, since a photo makes data of any observer useful. On the other hand, digital photography has displayed a significant number of erroneous identification even for professional ornithologists, that is why all facts about the Pallas's Fish Eagles distribution and nesting throughout the $20^{\text {th }}$ century should be treated critically.

Despite the recent findings, the Pallas's Fish Eagle is still a poorly understood species. The reasons for decreasing and subsequent fluctuations in its numbers throughout the $20^{\text {th }}$ century are still unclear. A case of Pallas's Fish Eagle shows how the lack of knowledge of the species biology results in too late introduction of protection measures. A protection status of the spe- 
водоёмов, а также рек с медменным течением, развитой поймой и большим количеством стариц и пойменных озёр. Об этом же свидетельствуют немногие имеюшиеся Аанные по GPS-телеметрии птиц. По этим Аанным, орлан-Аолгохвост избегает миительных перемешений в период межАу миграциями и средняя плошадь территории, занимаемой негнездяшейся птицей в период межАу миграциями составила лишь около 40-50 км² (Steele, 2017). Сроки миграций приходятся на весенние и осенние месяцы. ОАнако место встречи орланаАолгохвоста 23 июня 2018 г. на р. Чарыш мало напоминает места, гле обычно происходят встречи с Аолгохвостами в летний период, а по времени эта встреча не укиашывается в типичные сроки перелётов. Остаётся нацеяться, что увеличение числа исследований с использованием GPS-трекеров, а также мополнительные встречи вила на территории Алтайского края помогут понять, гАе проводят летние месяцы молодые орланы-долгохвосты.

Орлан-Аолгохвост Ааёт нам удивительный пример того, когАа более века наблюАений и исследований понадобилось, чтобы отбросить привычные представления и понять только в самых обших чертах биологию вида, разобраться с гнездовыми ареалами, сроками и направлением миграций, которое у этого вида оказалось инвертированным по отношению ко всем остальным мигрируюшим птицам северного полушария. Аия этого понацобились самые новые технические методы, вкиючая спутниковое слежение и различные базы Аанных, позволяюшие эффеекивно использовать инсрормацию, полученную не только профессиональными орнитологами, но и мюбителями. Широкое развитие цисровой фотограсрии слелало возможным Аокументирование наблюдений. Это оказалось особенно важным Аля такого редкого вила, как орлан-Аолгохвост, поскольку фотодоказательства позволили использовать данные непрофессионаиьных наблюдателей. С Аругой стороны распространение цисровой фотограсрии, продемонстрировало значительное количество случаев ошибочной идентификации Ааже профессионаиьными орнитологами, подтвержАая, что ко всем фактам о распределении и гнездовании Аолгохвоста на протяжении $\mathrm{XX}$ века нужно относится критически.

Несмотря на новейшие данные, орланАолгохвост остается малоизученным видом. cies was changed from vulnerable (VU) to endangered (EN) only in 2017, although it should have been done much earlier. The estimations of a number of mature individuals was decreased from 2500-9999 to 1000-2499, but the accuracy of this assessment is recognized to be insufficient and most likely it is far from the top level, while previous assessment were explicitly recognized as significantly overestimated (BirdLife International, 2018). Furthermore, according to the Zootierliste ${ }^{114}$ website, there is no captive conservation program today: there is only one Pallas's Fish Eagle (Deutsche Greifenwarte, Guttenberg, Germany) in all zoos of the EAZA association countries. For comparison, in Germany's zoos alone there are 55 Bald Eagles (Haliaeetus leucocephalus), 34 White-Tailed Sea Eagles and 15 Steller's Sea Eagles (Haliaeetus pelagicus).

Pallas's Fish Eagles suffer from usual hazards, associated with power lines, development of wind power and poaching, as other large raptors. Migration routes pass through the countries of South Asia, which is a region of the highest population growth and economic growth rates. The same applies to the Pallas's Fish Eagle breeding range, where destruction of the natural environment and landscapes industrialization are extremely rapid.

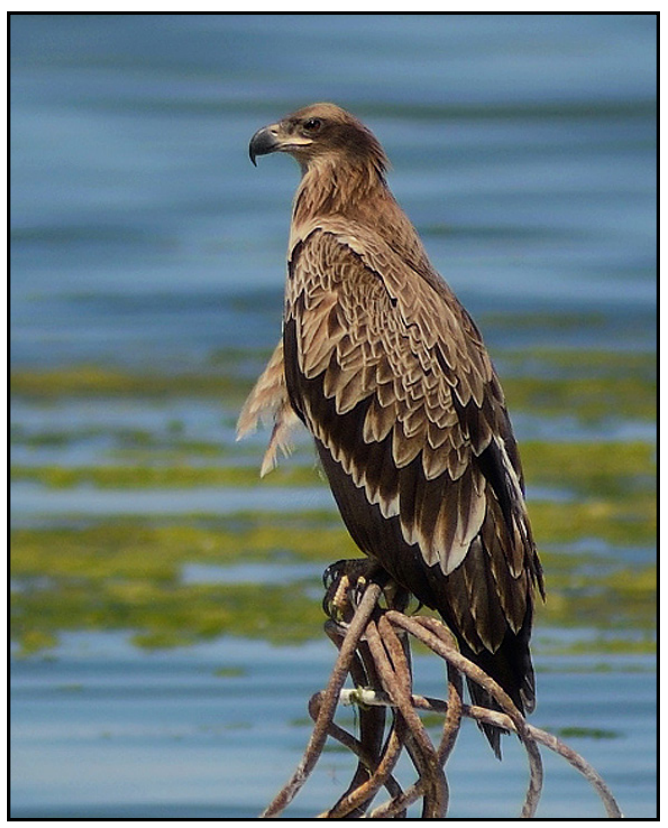

Молодой орлан-цолгохвост. Амматинская область, Сорбулак, 22.06.2014. Фото В. Федоренко.

Subadult Pallas's Fish Eagle. Almaty region, Sorbulak, 22/06/2014. Photo by V. Fedorenko. 


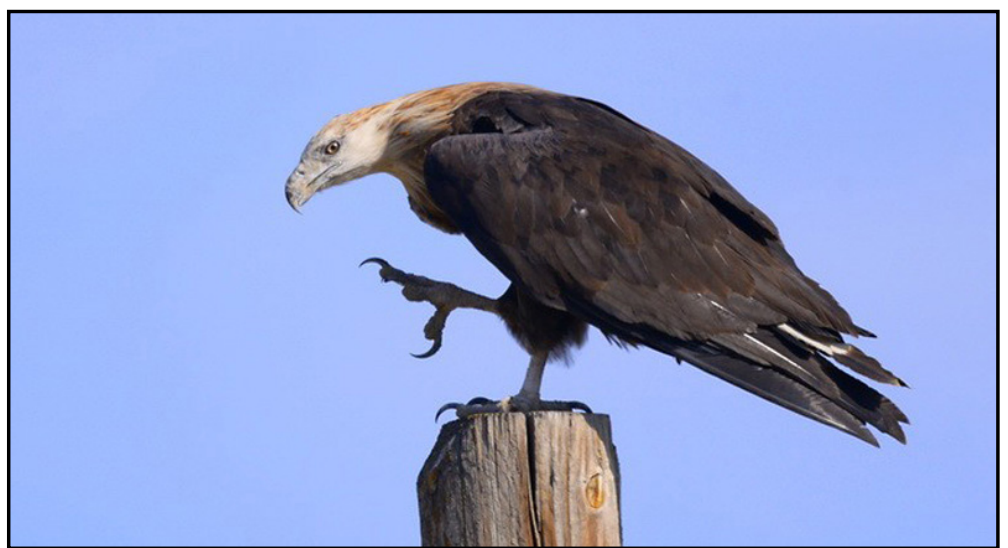

Взрослый орлан-долгохвост. Амматинская область, Карачингиль, 08.07.2014. Фото О. Белялова.

Adult Pallas's Fish Eagle. Almaty region, Karachingil, 08/07/2014. Photo by $O$. Belyalov. хишники Мира (Веб-ГИС "Фаунистика»). 2018. [Andreyenkov O., Andreyenkova N. Pallas's Fish Eagle (Haliaeetus leucoryphus). - Raptors of the World (Web-GIS "Faunistics"). 2018.] URL: http://raptors.wildlifemonitoring.ru/\#object/o_ $\mathrm{id=1} 15191$ Аата обрашения 15.11.2018.

Белялов О., Коваленко А.В., Фелоренко В.А. Орлан-долгохвост (Haliaeetus leucoryphus). - Пернатые хишники Мира (Веб-ГИС «Фаунистика»). 2018. [Belyalov O., Kovalenko A.V., Fedorenko V.A. Pallas's Fish Eagle (Haliaeetus leucoryphus). - Raptors of the World (Web-GIS "Faunistics"). 2010.] URL: http://raptors.wildlifemonitoring.ru Аата обрашения 15.11.2018.

Важов С.В. Орлан-долгохвост (Haliaeetus leucoryphus). - Пернатые хишники Мира (ВебГИС "Фаунистика»). 2010. [Vazhov S.V. Pallas's Fish Eagle (Haliaeetus leucoryphus). - Raptors of the World (Web-GIS "Faunistics"). 2010.] URL: http://raptors.wildlifemonitoring.ru/\#object/o_ id=131 Аата обрашения 15.11.2018.

Важков С.В. Бахтин Р.Ф. Встреча орлана-долгохвоста на озере Толбо-Нур, Баян-УАгийский аймак, Монголия. - Пернатые хишники и их охрана. 2010. № 19. С. 204-205. [Vazhov S.V., Bachtin R.F. Record of the Pallass Fish Eagle on Tolbo-Nur Lake, Bayan-Ulgii Province, Mongolia. - Raptors Conservation. 2010. 19: 204-205.] URL: http://rrrcn.ru/ru/archives/19351 Аата обрашения 15.11.2018.

Аементьев Г.П. ОтряА хишные птицы: Асcipitres или Falconiformes. - Птицы Советского Союза. Т. 1. М.: Сов. Наука, 1951. С. 70-341. [Dementiev G.P. Birds of prey: Accipitres or Falconiformes. - Birds of the Soviet Union. Vol. 1. Moscow, 1951: 70-341. (in Russian).] URL: http://rrrcn.ru/ru/archives/14389 Аата обращения 15.11.2018.

Карпов Ф.Ф., Белялов О.В. О встрече орланов-Аолгохвостов на Сорбулаке в 2008 г. - Казахстанский орнитологический бюметень 2008. Амматы: "Tethys", 2009. C. 163. [Karpov F.F., Belyalov O.V. About the records of the Pallas' Fish Eagle on Sorbulak Lake in 2008. - Kazakhstanian Ornithological Newsletter 2008. Almaty, 2009: 163. (in Rusian).] URL: https://issuu.com/ dd_nn/docs/kob2008/162 Аата обрашения 15.11.2018.

Коваленко А.В. Современные данные об орлане-долгохвосте в Казахстане. - Пернатые хишники и их охрана. 2009. № 15. С. 134-136 [Kovalenko A.V. Modern Records of the Pallas' Fish Eagle in Kazakhstan. - Raptors Conservation. 2009. 15: 134-136.] URL: http://rrrcn.ru/ru/archives/21104 Аата обрашения 15.11.2018.

Нацточий А.С. Залёт орлана-долгохвоста в Украину. - Хишные птицы в Аинамической среме третьего тысячелетия: состояние и перспективы. Труды VI международной консеренции по соколообразным и совам Северной Евразии, г. Кривой Рог, Украина, 27-30 сентября 2012 г. Кривой Рог, 2012. С. 512-514 [Nadtochiy A.S. Record of the Pallas's Fish Eagle in Ukraine. - 
Birds of Prey in the Dynamic Environment of the Third Millenium: Status and Prospects. Proceedings of the $6^{\text {th }}$ International Conference on Birds of Prey and Owls of North Eurasia, Kryvyi Rih, 27-30 September 2012. Kryvyi Rih, 2012: 512-514. (in Russian).] URL: http://rrrcn.ru/ wp-content/uploads/2014/05/62ks_4razdel.pdf $\triangle$ ата обрашения 15.11.2018.

Попов В.В. Орлан-долгохвост Haliaeetus leucoriphus на юге Сибири. - Русский орнитомогический журнал. 2002. экспресс-вып. 175. C. 124-130. [Popov V.V. Pallas's Fish Eagle Haliaeetus leucoryphus in southern Siberia. - Russian Ornithological Journal. 2002. Express-issue 175: 124-130. (in Russian).] URL: https://cyberleninka.ru/article/v/orlan-dolgohvost-haliaeetus-leucoryphus-na-yuge-sibiri $\triangle$ ата обрашения 15.11.2018.

Попов В.В. Встреча орлана-долгохвоста Haliaeetus leucoriphus в Верхнем Приангарье (Иркутская область). - Русский орнитологический журнал. 2018. Т. 27, экспресс-вып. 1616. C. 2524-2525. [Popov V.V. Records of the Pallas's Fish Eagle Haliaeetus leucoryphus in the Upper Angara River Basin (Irkutsk Region). - Russian Ornithological Journal. 2018. 27(1616): 25242525 (in Russian).] URL: https://cyberleninka.ru/ article/v/vstrecha-orlana-dolgohvosta-haliaeetus-leucoryphus-v-verhnem-priangarie-irkutskaya-oblast $\triangle$ ата обрашения 15.11.2018.

Попов В.В., Тупицын И.И. К распространению хишных птиц Северного Прихубсугулья, Монголия. - Пернатые хишники и их охрана. 2008. № 14. C. 116-117. [Popov V.V., Tupitsyn I.I. About the Distribution of Birds of Prey in Northern Hubsugul Lake Region, Mongolia. - Raptors Conservation. 2008. 14: 116-117.] URL: http:// rrrcn.ru/ru/archives/25561 Аата обрашения 15.11.2018.

Феселов И.В. Неверная видовая идентисрикация гнездяшейся хишной птицы из БокейорАинского района Западно-Казахстанской области. - Русский орнитологический журнал. 2016. Т. 25, экспресс-вып. 1319. С. 2859-2860. [Fefelov I.V. Invalid identification of nesting birds of prey species from Bokeyorda district of Western Kazakhstan region. - Russian Ornithological Journal. 2016. 25(1319): 2859-2860 (in Russian).] URL: https://cyberleninka.ru/article/v/nevernaya-vidovaya-identifikatsiya-gnezdyascheysyahischnoy-ptitsy-iz-bokeyordinskogo-rayona-zapadno-kazahstanskoy-oblasti Аата обрашения 15.11.2018.

Шнайлер Е.П. Орлан-долгохвост (Haliaeetus leucoryphus). - Пернатые хищники Мира (ВебГИС "Фаунистика»). 2016. [Shnayder E.P. Pallas's Fish Eagle (Haliaeetus leucoryphus). - Raptors of the World (Web-GIS "Faunistics"). 2016.] URL: http://raptors.wildlifemonitoring.ru/\#object/o_ id=90620 Аата обрашения 15.11.2018.

Цыбулин С.М. Птицы северного Аитая. Новосибирск, 1999. 520 с. [Tsybulin S.M. Birds of northern Altai. Novosibirsk, 1999: 1-520. (in Russian).]
BirdLife International. Haliaeetus leucoryphus. - The IUCN Red List of Threatened Species 2018: e.T22695130A131934599. 2018. DOI: 10.2305/IUCN.UK.2018-2.RLTS. T22695130A131934599.en. URL: https://www. iucnredlist.org/species/22695130/131934599 $\triangle$ ата обрашения 15.11.2018.

eBird. Орлан-Аолгохвост (Haliaeetus leucoryphus)круглыйгод,2010-2018.2018.URL:https:// ebird.org/india/map/pafeag 1 ? neg=true\&env. $\min X=-65.29920312499996 \&$ env. $\min Y=$ $32.507998709603896 \&$ env.max $X=$ $121.1976406249999 \&$ env. $\max Y=71.088982$ $34634945 \& \mathrm{zh}=$ true $\& \mathrm{gp}=$ true $\&$ ev $=\mathrm{Z} \& \mathrm{mr}=1$ $12 \&$ bmo $=1 \&$ emo $=12 \& \mathrm{yr}=$ range $\&$ byr $=2010 \& \mathrm{e}$ $\mathrm{yr}=2018$ Аата обрашения 15.11.2018.

Gilbert M., Tingay R., Losolmaa J., Sureda N., Gilbert C., Batmunkh D., Gombobaatar S. Distribution and status of the Pallas's Fish Eagle Haliaeetus leucoryphus in Mongolia: A cause for conservation concern? - Bird Conservation International. 2014. 24(3): 379-388. DOI:10.1017/ S0959270913000543 URL: https://www. researchgate.net/profile/Martin_Gilbert/publication/268576035_Distribution_and_status_of_the_Pallas's_Fish_Eagle_Haliaeetus_leucoryphus_in_Mongolia_A_cause_for_conservation_concern/links/54709c4d0cf216f8cfaa1286/ Distribution-and-status-of-the-Pallass-FishEagle-Haliaeetus-leucoryphus-in-Mongolia-Acause-for-conservation-concern.pdf $\triangle$ ата обрашения 15.11.2018.

Inskipp C., Baral H.S., Phuyal S., Bhatt T.R., Khatiwada M., Inskipp T, Khatiwada A., Gurung S., Singh P.B., Murray L., Poudyal L., Amin R. The status of Nepal's Birds: The national red list series. Vol. 1. Zoological Society of London, UK., 2016: 1-678. URL: https://www.researchgate. net/publication/312303875_The_Status_of_ Nepal\%27s_BirdsThe_National_Red_List_Series_ VOLUME_1 Аата обрашения 15.11.2018.

Knappen-von den Driesch $U$. Pallas's Sea-Eagle Haliaeetus leucoryphus (Pallas, 1771). - Kazakhstan Birdwatching community. 2008. URL: http://www.birds.kz/v2photo. php?l=en\&s $=004600001 \& n=1 \&$ si $=k a z \Delta$ ата обрашения 15.11.2018.

RRRCN. Raptors of the World. Version 1.3. Sibecocenter LLC. 2018. DOI: $10.15468 / \mathrm{fggsfn}$ Occurrence Dataset https://doi.org/10.15468/ fggsfn accessed via GBIF.org on 2018-11-15.

Sourav M.S.H., Ahmed B., Thompson P. Pallas's Fish Eagle Haliaeetus leucoryphus in Bangladesh. - BirdingASIA. 2011. 16: 101-105. URL: https://www.researchgate.net/publication/279753077_Pallas's_Fish_Eagle_Haliaeetus_leucoryphus_in_Bangladesh Аата обрашения 15.11.2018.

Steele M.L. Where in the World are Pallas's Fish Eagles? Migration and Ecology of Haliaeetus leucoryphus in Asia. Theses and Dissertations. Oklahoma State University, 2017: 1-122. URL: https://scholarworks.uark.edu/etd/2015 Дата обрашения 15.11.2018. 